\section{Sensory Nerve Terminations in the Epidermis of the Blowfly Larva}

IT has been known for many years that a plexus of multipolar neurones is associated with the epidermis of many insects, especially in the soft-skinned larvæ of Lepidoptera, Coleoptera, and Diptera. Previous descriptious of the dendritic terminations have been restricted to light-microscopical investigations on material stained vitally with methylene blue. The findings of earlier workers on this subject have been reviewed by Snodgrass ${ }^{1}$, who concluded that the dendrites terminate on the basement membrane covering the epidermal cells. Accounts of more recent work on the sub-epidermal nerve plexus of insects ${ }^{2-5}$ also support this conclusion. However, electron-microscopic investigations made by the author on the subepidermal nerve plexus of the blowfly larva, Phormia terrae-novae, indicate that the dendrites do not terminate on the basement mombrane, and the results of preliminary investigations are given here.

The cell bodies and processes of the neurones are ensheathed by Schwann cells. A characteristic feature of this sheath is the inclusion of fluid-filled spaces (Fig. $(A-F)$, the significance of which is being investigated. Immediately surrounding the Sehwann cell sheath is a layer of basement membrane material or connective tissue. Although the cell bodies and major dendritic branches are situated in the hæmolymph space, they are anchored by strands of connective tissue to the basement membrane covering the epidermal cells. At the junction between a dendrite and the epidermis, the basement membranes covering the Schwann cell and the opidermal cell fuse. Afterwards, the ensheathed dendrite penetrates the basement membrane of the epidermis and lies in a channel formed by an indentation in the surface of the epidermal cell (Fig. $1 A-D$ ). The apposed plasma membranes of the Schwann and epidermal cell are attached to one another by desmosomes. The dendrite and sheath penetrate deeper into the epidermal cell until they are completely surrounded by jt. Eventually, the dendrite emerges from the Schwann cell sheath and is enveloped by the invaginated plasma membrane of the epidermal cell (Fig. $1 E, F$ ). A space of $100 \AA$ separates the apposed plasma membranes of the dendrite and epidermal cell. As the dendrites could not be traced any further than this level, it is likely that the sheath-froo process is the terminal region. It is clear, however, that the dendrites do not terminate on the basement membrane of the epidermal cells.

Recent electron-microscopic investigations on vertebrate muscle spindles ${ }^{6,7}$, the Pacinian corpusclo ${ }^{8}$, and the cockroach longitudinal stretch receptor ${ }^{9}$ have revealed that the sensory terminations are naked, that is, they have no Schwann cell investment. Therefore, in the blowfly larva it seems plausible that the naked regions of the dendrites are the receptor sites. It is generally agreed that the multipolar neurones innervating the epidermis of insects subserve a proprioceptive function ${ }^{10}$. Thus it is reasonable to assume that mechanical deformation of the epidermal cells distorts the naked nerve endings in some way, and sets in motion the sequence of events that culminates in the initiation of the action potential in the axon of the sensory neurone.

A detailed examination of the peripheral nerves and sensory terminations of multipolar neurones of the blowfly larva is in progress, and the results will be pub lished elsowhere.

Tho electron-microscope, an Akashi tronscopo, TRS50E1, was provided by the Welleome Trust for
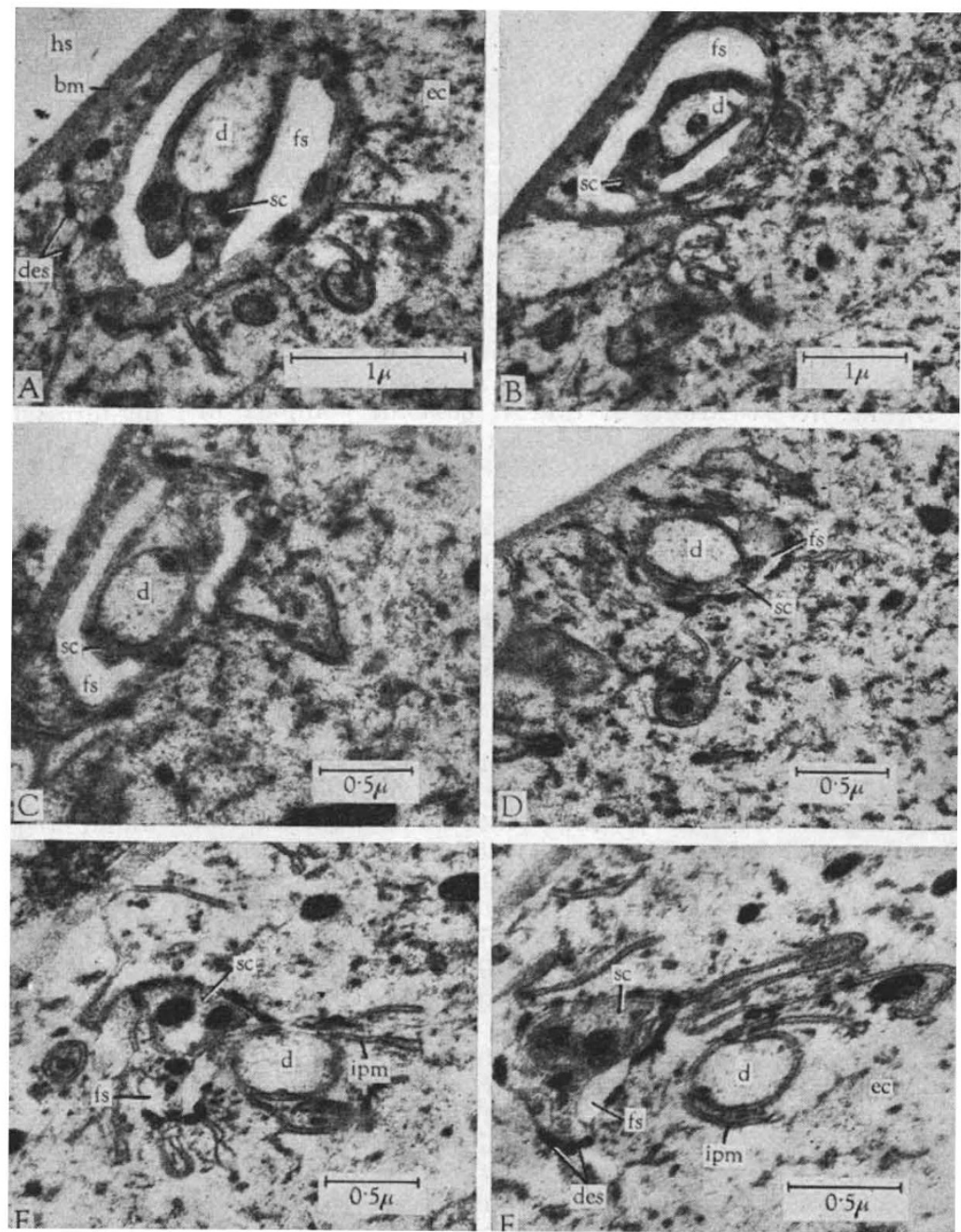

Fig. 1. A selection of electron-micrographs taken from serial sections through a dendrite of one of the multipolar neurones associated with the epidermis of the blowfly larva, cell sheath $(s c)$ surrounding the dendrite $(d)$ until in sections $E$ and $F$ the dendrite is enveloped only by the invaginated plasma membrane (ipm) of the epidermal cell (ec) Preparation fixed in osmic acid, stained with phosphotungstic acid, and embedded in 'A raldite'. bm, Basement membrane; des, desmosome; $f_{s}$, fluid-filled space; $h s$, hæmolymph space

research work earried out under the directorship of Prof. O. E. Lowenstein.

M. P. OsBorne

Department of Zoology and Comparative Physiology, University of Birmingham.

${ }^{1}$ Snodgrass, R. E., Smithson. Misc. Coll., 77, 1 (1926).

${ }^{2}$ Meyer, G. F., Zool. Jb. Anat., 74, 339 (1955)

${ }^{3}$ Barbier, R., Ann, Sei. Nat, Zool., 3, 173 (1961).

4 Hamon, M., Ann. Sci. Nat. Zool., 3, 153 (1961).

${ }^{5}$ Osborne, M. P., Quart. J. Micro. Sci., 104, 227.

"Katz, B., Phil. Trans. Roy. Soc., B, 243, 221 (1961).

'Merrillees, N. C. R., J. Biophys. Biochem. Cytol., 7, 725 (1960).

${ }^{8}$ Pease, D. C., and Quilliam, T. A., J. Biophys. Biochem. Cytol., 3, 331 (1957).

Osborne, M. P., J. Insect. Physiol., 9, 237 (1963).

${ }^{10}$ Pringle, J. W. S., in The Cell and the Organism, 256 (Camb. Univ. Press, 1961) 